\title{
ANALISA HUKUM PUTUSAN \\ NOMOR: 28/MEREK/2011/PENGADILAN NIAGA JAKARTA SENGKETA MEREK ANTARA MEREK CALCIMAX DENGAN MEREK CALCIMEX
}

\author{
Ali Sutiyo Syaifullah \\ Fakultas Hukum Universitas Tri Tunggal Surabaya \\ e-mail: ali.sutiyo@gmail.com
}

\begin{abstract}
ABSTRAK
Penelitian ini bertujuan untuk memahami dan mengalisis putusan Pengadilan Niaga tentang bagaimana hakim menilai keterkenalan suatu merek berdasarkan beberapa gugatan pembatalan merek di Indonesia yang dilakukan pengusaha asing terhadap pengusaha lokal dengan analisis putusan No. 28/MEREK/2011/PN.NIAGA.JKT.PST. antara Calcimax dan Calcimex. Pengusaha lokal pemilik merek Calcimax dimenangkan karena terbukti tidak ada niat untuk membonceng, meniru atau menjiplak ketenaran merek Calcimex demi kepentingan usahanya. Selain itu juga terbukti bahwa pendaftaran merek Calcimax juga tidak menimbulkan kondisi persaingan curang, mengecoh, atau menyesatkan konsumen. Dengan kata lain, pihak pengusaha lokal pemilik merek Calcimax disini mendaftarkan mereknya secara layak dan jujur. Kata Kunci: merek, itikad baik, pengusaha.
\end{abstract}

\section{ABSTRACT}

This research was intended to review and analyze the verdicts also discusses how judges assess the fame of a trademark based on some of the lawsuit claimed by foreign entrepreneur to local entrepreneurs as a case study takes verdict No. 28/MEREK/2011/PN.NIAGA.JKT.PST. between Calcimax and Calcimex. In this dispute, the local entrepreneur, Calcimax trademark owner won because it proved no intention to pass off, imitate or trace Calcimex's notoriety for his business purposes. It also proved that Calcimax trademark registration didn't cause unfair competition, deceptive, or misleading the consumer. In other words, local entrepreneur who is Calcimax brand owner registered his brand properly and honestly.

Keywords: trademark, good faith, businessman.

\section{PENDAHULUAN}

Sebagai bagian dari sistem hukum, hak kekayaan intelektual sangat erat kaitannya dengan industri, perdagangan dan investasi. Singkatnya, hak kekayaan intelektual sangat erat kaitannya dengan dunia usaha. Produk-produk yang berkualitas dan handal hanya dapat dihasilkan jika sistem hak kekayaan intelektualnya sudah baik. Adanya hak kekayaan intelektual merangsang peningkatan karya intelektual serta penelitian dan pengembangan yang mampu menghasilkan teknik dan teknologi-teknologi baru yang akan menggairahkan dunia usaha. Perlunya perlindungan hukum terhadap merek karena merek mempunyai nilai ekonomi atas suatu barang dan jasa yang menunjukkan kualitas barang dan jasa tertentu dalam perdagangan, dan membedakan dengan nilai atau kualitas dengan barang dan jasa sejenis milik orang lain. Untuk mendapatkan perlindungan hukum, suatu merek harus didaftar. Pendaftaran merek juga berguna sebagai dasar penolakan terhadap merek yang sama keseluruhannya atau sama pada pokoknya yang dimohonkan oleh orang lain yang dengan itikad tidak baik untuk barang dan jasa sejenis.

Sampai sekarang masih terdapat ketidakjelasan mengenai kriteria yang harus dipenuhi hingga dapat dikatakan terkenal. Merek terkenal sebagaimana tertuang dalam Pasal 6 ayat (1) huruf b UndangUndang No. 15 Tahun 2001 tentang Merek menegaskan bahwa ketentuan mengenai perlindungan merek terkenal merupakan permohonan yang harus ditolak oleh Direktorat Jenderal apabila merek tersebut 
mempunyai persamaan dengan merek yang terkenal milik pihak lain untuk barang dan/atau jasa sejenis. Para ahli pun sepakat untuk tidak mendefinisikan. Sering terdapat masalah karena hal ini.

Sejauh ini batasan secara umum mengenai merek terkenal adalah suatu kriteria penggolongan, reputasi, kualitas, penjualannya stabil, reputasi, kualitas, penjualan stabil, diperdagangkan di berbagai negara, mendaftarkan mereknya di berbagai negara, pengetahuan masyarakat dan promosinya. ${ }^{1}$ Pentingnya perlindungan hukum terhadap merek dagang yang beritikad baik sangat diperlukan karena dalam sengketa merek terkenal, pengusaha nasional yang digugat oleh pengusaha asing selalu dikalahkan. Hal ini dikarenakan anggapan yang telah disandang oleh masyarakat Indonesia sebagai bangsa yang suka mencontoh bangsa lain. Anggapan tersebut tidak hanya di mata bangsa asing, namun bangsa Indonesia sendiri juga beranggapan sama.

Hal tersebut terbukti dari banyaknya kasus yang dimenangkan oleh pihak asing atas pihak lokal dalam sengketa merek yang hakimnya merupakan Bangsa Indonesia. Namun hal ini perlu ditinjau kembali, jika ada pihak beritikad baik dan telah mengeluarkan banyak biaya demi mengembangkan merek miliknya, maka pihak tersebut akan menderita kerugian. Jika kejadian tersebut terjadi secara terusmenerus, akan mengakibatkan terjadinya kelesuan pada pihak nasional dalam dunia usaha yang akan mengakibatkan kerugian terhadap perekonomian negara kita sendiri.

Pemeriksaan merek terkenal oleh Direktorat Jenderal Merek harus berhati-hati karena dapat menyesatkan. Lebih baik mengutamakan itikad baik dari si pemohon pendaftaran merek. Jangan selalu menganggap Pasal 6 ayat (1) huruf b Undang-Undang No. 15 Tahun 2001 tentang Merek (selanjutnya disebut UUM), sebagai pedang sakti yang harus menyatakan permohonan harus ditolak oleh Direktorat Jenderal Merek apabila merek tersebut memiliki persamaan pada pokoknya atau keseluruhannya dengan merek yang sudah terkenal milik pihak lain untuk barang dan/atau jasa yang sejenis. ${ }^{2}$ Penelitian mengenai kasus sengketa merek

1 Bagir Manan, Hak Kekayaan Intelektual dan Perkembangannya. Pusat Pengkajian Hukum, Jakarta, 2005, h. 180-181.

2 Insan Budi Maulana, Bianglala Haki: Hak Kekayaan Intelektual, Hecca Mitra Utama, Jakarta, 2005, h. 193. antara pengusaha lokal dan pengusaha asing penulis mengambil contoh kasus yaitu perkara dengan nomor putusan 28/MEREK/2011/PN.NIAGA.JKT.PST. antara Calcimax dan Calcimex.

Memperhatikan uraian di atas bisa dijelaskan bahwa pemilik merek dari warga negara atau pengusaha asing dapat memperoleh merek di Indonesia walaupun terdapat persamaam pada pokoknya. Berdasarkan uraian sebagaimana tersebut, maka yang dipermasalahkan dalam penulisan ini adalah Apakah Pendaftaran Merek Calcimax pada Dirjen HKI Departemen Hukum dan HAM mempunyai persamaan pada pokoknya dengan merek lain berdasarkan Pasal 6 UUM, dan Apakah Pertimbangan hukum yang menjadi dasar putusan Pengadilan Niaga Jakarta Nomor: 28/Merek/2011/ PN.Jkt.Pst. Tahun 2011.

\section{PEMBAHASAN}

\section{Pendaftaran Merek Calcimax pada Dirjen HKI Departemen Hukum dan HAM Mempunyai Persamaan pada Pokoknya dengan Merek Lain}

Bahwa ketentuan merek dalam UUM Pasal 1 angka 1 menegaskan bahwa Merek adalah tanda yang berupa gambar, nama, kata, huruf-huruf, angkaangka, susunan warna, atau kombinasi dari unsurunsur tersebut yang memiliki daya pembeda dan digunakan dalam kegiatan perdagangan barang atau jasa.

Di dalam UUM di atas ditekankan bahwa merek perlu memiliki daya pembeda. Maksudnya adalah tanda yang digunakan sebagai merek tidak boleh terlalu sederhana dan tidak boleh terlalu rumit sehingga menjadi tidak jelas. ${ }^{3}$ Merek yang bentuknya sederhana dan terlalu rumit akan membingungkan masyarakat apakah tanda itu sebagai merek atau bukan. Menurut Gautama hal ini tidak dapat memberi kesan dari suatu merek. Agar saat memberikan individualitas kepada suatu benda maka merek yang bersangkutan harus memiliki kekuatan-kekuatan individualitas. $^{4}$

Persetujuan TRIPs, khususnya Pasal 15 ayat (1) mengatur tentang definisi merek sebagai berikut: Tanda-tanda atau kombinasi dari tanda-tanda, mampu membedakan barang atau jasa dari salah

\footnotetext{
${ }^{3}$ Penjelasan Pasal 5 huruf b Undang-Undang Nomor 15 Tahun 2001 tentang Merek.

${ }^{4}$ Rachmadi Usman, Hukum Hak atas Kekayaan Intelektual, Alumni, Bandung, 2003, h. 38.
} 
satu usaha dari merek dagang mereka. Tandatanda seperti, di kata-kata tertentu termasuk nama pribadi, surat, angka, unsur figuratif dan kombinasi warna serta kombinasi dari tanda-tanda tersebut, harus memenuhi syarat untuk pendaftaran sebagai merek dagang. Dimana tanda-tanda tidak inheren mampu membedakan barang atau jasa yang relevan. Anggota dapat membuat registrability tergantung pada kekhasan yang diperoleh melalui penggunaan. Anggota mungkin memerlukan, sebagai syarat pendaftaran, bahwa tanda-tanda akan secara visual (Terdapat dalam Persetujuan TRIPs Pasal 15 ayat 1).

\section{Kasus Posisi}

Kasus ini bermula dari gugatan Frisland Brand B.V. selaku Penggugat, suatu perseroan berdasarkan Undang-Undang Negara Belanda, yang berkedudukan di Blakerstein 142, 7943 PE MEPPEL, Belanda terhadap PT Suryapratama Nutrisindo yang berdudukan di Jl. Gunung Sahari Raya No. 41 Jakarta Pusat selaku Tergugat I dan Pemerintah Republik Indonesia cq. Departemen Hukum dan Hak Asasi Manusia cq. Direktur Jenderal Hak Kekayaan Intelektual cq. Direktorat Merek selaku Tergugat II, terkait merek Calcimax yang dianggap telah didaftarkan dengan itikad tidak baik oleh Tergugat I.

Dalam hal ini, Penggugat adalah pemilik merek Calcimex sejak tahun 1994 yang didaftarkan untuk melindungi kelas barang yang termasuk dalam kelas 5, 29 dan 30, antara lain:

Pertama, Kelas 5 menegaskan bahwa substansi gizi untuk keperluan medis, khususnya minuman susu dan susu bubuk dengan tambahan-tambahan.

Kedua, Kelas 29 menegaskan bahwa susu dan produk susu, termasuk yang dicampur dengan produk- produk lain (dengan unsur-unsur utama susu dan produk susu) dan bahan pengganti untuk itu dan produk-produk yang dibuat daripadanya sebatas tidak termasuk dalam kelas lain, khususnya minuman susu dan susu bubuk, baik yang ditambahkan cita rasa dan/atau aditif gizi maupun tidak.

Ketiga, Kelas 30 menegaskan bahwa kakao, gula beras, tapioka, sagu; produk yang terdiri dari atau terutama dibuat dari produk tersebut, khususnya susu coklat dan minuman kakao, baik yang ditambahkan cita rasa dan/atau aditif gizi maupun tidak, serta produk-produk tersebut di atas dalam bentuk yang dapat dilarutkan untuk membuat minuman-minuman tersebut.
Penggugat mendalilkan bahwa mereknya merupakan merek terkenal karena telah diproduksi dan diperdagangkan secara berkesinambungan serta dipromosikan dengan biaya yang sangat besar dan juga telah terdaftar di mancanegara, sehingga merekmerek penggugat telah lama menembus batas-batas nasional dan internasional yang mempunyai wawasan globalisasi dan tidak mengenal batas dunia atau borderless world.

Penggugat telah mendaftarkan mereknya di Indonesia sejak tahun 1994 di bawah daftar No. 342289 yang diperpanjang pada tanggal 28 April 2004 di bawah daftar No. IDM00016054 untuk melindungi jenis barang kelas 29 yaitu susu dan hasil-hasil produk susu. Mengingat Undang-Undang Merek di Indonesia menganut sistem konstitutif maka konsekuensinya berlaku asas prior in fempora nelior in jure yang berarti siapa yang pertama kali mendaftar, maka ia yang berhak mendapatkan perlindungan hukum atau the first to file principle.

Selain terdaftar di Indonesia, Penggugat juga telah mendaftarkan mereknya di berbagai negara di dunia, yakni: Benelux, Thailand, Nigeria, Uni Emirat Arab dan Singapura. Namun setelah melakukan pengecekan ternyata pada Direktorat Merek (Tergugat II) telah terdaftar merek dagang Calcimax atas nama Tergugat I di bawah daftar No. IDM000090867 tanggal 26 Juli 2004 untuk melindungi jenis barang yang termasuk ke dalam kelas 05 yaitu vitamin.

Penggugat dalam hal ini sangat keberatan dengan pendaftaran dengan merek dagang Calcimax kelas 5 di bawah daftar No. IDM000090867 atas nama Tergugat I karena memiliki persamaan pada pokoknya dengan merek Calcimex milik Penggugat, mengingat terdapat kemiripan yang disebabkan adanya unsurunsur yang menonjol antara merek dagang Calcimax atas nama Tergugat I dengan merek dagang terkenal Calcimex milik Penggugat yang dapat menimbulkan kesan adanya persamaan baik mengenai bentuk, cara penempatan, cara penulisan atau kombinasi antara unsur-unsur atau persamaan bunyi ucapan yang terdapat pada merek-merek tersebut.

Penggugat mendalilkan bahwa masih banyak kata atau kalimat lain selain Calcimax yang dapat didaftarkan atau digunakan sebagai merek oleh Tergugat I, namun ironisnya penggugat I justru memaksakan kehendaknya dengan menggunakan atau mendaftarkan merek Calcimax yang memiliki 
persamaan dengan merek Calcimex, Penggugat yang telah terkenal. Menurut Penggugat mustahil tergugat I yang notabene perusahaan Indonesia dapat menciptakan merek Calcimax begitu saja, mengingat kata atau kalimat Calcimax bukanlah kata yang lazim digunakan dalam pergaulan Bangsa Indonesia.

Penggugat mendalilkan bahwa tidak dapat disangkal lagi bahwa Tergugat I memiliki itikad tidak baik dalam mendaftarkan merek dagang Calcimax kelas 05 dengan daftar No. IDM000090867 dan secara tidak jujur meniru, menjiplak atau membonceng ketenaran merek dagang Calcimex Penggugat demi kepentingan usaha Tergugat I secara jalan pintas atau passing off yang berakibat kerugian pada pihak penggugat atau menimbulkan persaingan curang, ceroboh atau menyesatkan konsumen untuk menentukan asal-usul suatu produk. Hal tersebut menurut tergugat sangat bertentangan dengan ketentuan Pasal 6 ayat (1) butir b jo. Pasal 4 UUM.

Penggugat mendalilkan bahwa ia merasa sangat berkepentingan atau beralasan hukum untuk menggugat Tergugat I agar mereknya dinyatakan batal demi hukum. Dimana hal tersebut sesuai dengan maksud dan tujuan utama keberadaan UUM yaitu untuk melindungi iklim persaingan usaha yang sehat dan mencegah pihak-pihak tertentu dalam membonceng reputasi pihak lain secara melawan hukum dengan cara membajak mereknya secara sama keseluruhan atau sama pada pokoknya.

Penggugat mendalilkan bahwa keikutsertaan Indonesia dalam mengikuti Konferensi Stockholm wajib melindungi merek-merek terkenal, sehingga dengan demikian wajib melindungi pendaftaran merek Calcimex Penggugat yang telah terkenal dan wajib membatalkan merek Calcimax dengan daftar No. IDM000090867 kelas 05 atas nama Tergugat I yang terdaftar pada tergugat II, karena merupakan peniruan atau penjiplakan dari merek terkenal Calcimex Penggugat.

Oleh karena itu, Penggugat menyatakan bahwa merek dagang Calcimex miliknya merupakan merek terkenal dan telah terdaftar di berbagai negara di dunia merasa bahwa hasil imajinasinya telah dijiplak dan ditiru oleh Tergugat I, maka berdasarkan ketentuan Pasal 68 ayat (1) UUM, Penggugat mempunyai kepentingan untuk melakukan gugatan pembatalan terhadap pendaftaran merek Calcimax daftar No. IDM000090867 atas nama Tergugat I dan diikutsertakannya Tergugat II adalah untuk mentaati isi putusan pengadilan untuk membatalkan merek dagang Calcimax dengan daftar No. IDM000090867 kelas 05 atas nama Tergugat I dari Daftar Umum Merek sebagaimana ketentuan Pasal 70 ayat (3) UUM.

Tergugat I menyatakan bahwa jelas dan terang merek Calcimex milik Penggugat berbeda penamaan dengan merek Calcimax milik Tergugat I, apalagi merek Penggugat Calcimex untuk melindungi jenis barang yang termasuk dalam kelas 05, 29 dan 30, sedangkan merek Tergugat I Calcimax untuk melindungi jenis barang hanya kelas 05 saja yaitu vitamin. Dalam hal ini, Penggugat lebih menunjukkan rasa kekhawatiran yang berlebihan, oleh karena walaupun Penggugat telah menyatakan sebagai pebisnis besar dan internasional, serta merekmerek penggugat telah lama menembus batas-batas nasional dan internasional, namun penggugat melihat ada nama yang lebih baik karena menggunakan kalimat Max (Calcimax).

Tergugat I menyatakan bahwa walaupun Penggugat merasa mempunyai hak eksklusif dan pendaftar pertama atas merek terkenal Calcimex serta terdaftar pula di berbagai negara di dunia, tetapi penggugat tidak berhak melarang Tergugat I untuk mendaftarkan dan menggunakan merek Calcimax yang jelas-jelas berbeda dengan merek dan jenis barang yang dimiliki penggugat yang tidak terdapat kesamaan atau terdapat kemiripan dengan merek Penggugat, mengingat Tergugat I memakai merek Calcimax dengan kelas barang dan jasa 05, didaftarkan ke Dirjen HKI cq Direktorat Merek melalui Konsultan HKI, bernama: Efendi, beralamat di Jalan Gunung Sahari Raya No. 41 Jakarta Pusat, dimohonkan pada tanggal 26 Juli 2004, dengan nomor permohonan merek: D00-2004-21002-21167, setelah dilakukan penelitian dan pemeriksaan dari Dirjen HKI selama 2 tahun, baru tanggal 29 Juli 2006 Tergugat I diberikan hak atas merek Calcimax oleh Dirjen HKI cq Direktorat merek dengan nomor merek IDM000090867;

Tergugat I menyatakan bahwa pernyataan pada Penggugat yang mengatakan mustahil Tergugat I yang notabenenya Perusahaan Indonesia bisa menciptakan nama Calcimax yang tidak lazim dalam pergaulan Bangsa Indonesia harus ditolak oleh karena lebih merupakan penghinaan Penggugat yang berasal dari Belanda terhadap orang Indonesia yang berpendapat seolah-olah Warga Negara Indonesia bodoh. 
Tergugat I menyatakan bahwa tidak ada sama sekali niat atau itikad tidak baik dari Tergugat I dalam Pendaftaran Merek Calcimax kelas 05 Daftar No. IDM000090867, tidak layak, tidak jujur untuk membonceng, meniru atau menjiplak ketenaran merek Penggugat Calcimex, oleh karena tidak mungkin permohonan Tergugat I untuk memakai merek Calcimax dapat dikabulkan oleh Dirjen HKI Cq. Direktorat Merek, apabila Tergugat I mempunyai sifat-sifat tercela, serta selama ini tidak ada konsumen yang bingung antara merek Calcimax dengan merek Calcimex karena jika diperhatikan secara seksama dan detail, jenis barang yang tertera dalam merek Calcimex milik Penggugat adalah sangat berbeda dengan merek Calcimax milik Tergugat I. Jenis barang yang tertera pada merek Calcimex kelas 05 untuk jenis barang berkaitan dengan substansi gizi untuk keperluan medis, khususnya minuman susu dan susu bubuk dengan tambah-tambahan. Untuk saat ini Direktorat Jenderal HKI cq Direktorat Merek tidak lagi dapat menerima permohonan pendaftaran merek untuk jenis barang seperti tersebut di atas, karena dalam hal ini pengertian jenis barang tersebut terlalu luas.

Bahwa benar sesuai dengan data yang terdapat dalam Daftar Umum Merek Tergugat II adalah:

Pertama, Merek Calcimax yang tercantum dalam daftar No. IDM000090867 untuk melindungi jenis barang vitamin yang termasuk kelas 05 atas nama PT. Surya Prana Nutrisindo/Tergugat. Merek Calcimex daftar No. 000016054 untuk melindungi jenis barang susu dan hasil-hasil produksi susu yang termasuk kelas 29 atas nama Penggugat;

Kedua, Merek Calcimex Vitalize yang tercantum dalam daftar No. IDM000183280 untuk melindungi jenis barang susu dan produk-produk susu, termasuk yang dicampur dengan produk lainnya (dengan susu atau produk susu sebagai unsur utama), pengganti susu, dan produk-produk yang terbuat dari susu (tidak termasuk di kelas lainnya), khususnya minuman susu, susu bubuk baik dengan tambahan aroma dan/atau makanan maupun tidak, yoghurt, susu kental manis maupun tawar, susu tanpa lemak yang termasuk kelas 29 atas nama Penggugat;

Ketiga, Merek Calcimex Vitagold daftar No. IDM000183281 untuk melindungi jenis barang susu dan produk-produk susu, termasuk yang dicampur dengan produk lainnya (dengan susu atau produk susu sebagai unsur utama), pengganti susu dan produk- produk yang terbuat dari susu (tidak termasuk di kelas lainnya), khususnya minuman susu, susu bubuk baik dengan tambahan aroma dan/atau makanan maupun tidak, yoghurt, susu kental manis maupun tawar, susu tanpa lemak yang termasuk kelas 29 atas nama Penggugat;

Keempat, Merek Calcimex Vitalize daftar No. IDM000166617 untuk melindungi jenis barang kakao, produk-produk kakao (atau mengandung kakao sebagai unsur utama), khususnya minuman dengan bahan dasar coklat, minuman coklat dengan susu, susu coklat, baik dengan tambahan rasa maupun tidak, dan juga sedia-sediaan tersebut di atas dalam bentuk yang dapat dilarutkan, untuk membuat minuman-minuman tersebut, tepung, makanan dan sediaan makanan dari padi-padian, yang termasuk kelas 30 atas nama Penggugat.

Tergugat II menyatakan bahwa sesuai dengan ketentuan dalam Pasal 3 jo. Pasal 28 UUM disebutkan bahwa hak atas merek adalah hak eksklusif diberikan negara kepada pemilik merek yang terdaftar dalam Daftar Umum Merek dalam jangka waktu tertentu dengan mengggunakan sendiri merek tersebut atau memberikan izin kepada pihak lain untuk menggunakannya. Sehubungan dengan kedua merek sengketa tersebut telah terdaftar dalam Daftar Umum Merek baik atas nama Tergugat I maupun atas nama Penggugat telah dilindungi oleh negara untuk jangka waktu 10 Tahun.

Tergugat II membenarkan bahwa undang-undang di bidang merek sebagaimana tercermin dalam Pasal 3 UUM adalah mengadopsi sistem konstitutif di mana perlindungan hukum hanya diberikan terhadap merek-merek yang telah terdaftar dalam Daftar Umum Merek dan hak tersebut diperoleh melalui mekanisme permintaan pendaftaran merek (mengingat permintaan pendaftaran merek tidaklah menjadi suatu kewajiban bagi pelaku usaha). Sistem konstitutif dapat direalisasikan dengan didukung oleh sistem First to File, akan tetapi sesuai dengan data yang diperoleh di Direktorat Merek bahwa merek Calcimex atas nama Penggugat untuk jenis barang vitamin yang termasuk dalam kelas 05 belum terdaftar dalam Daftar Umum Merek, dengan demikian terdaftarnya merek Calcimax atas nama Tergugat I untuk melindungi jenis barang vitamin yang termasuk dalam kelas 05 secara hukum sudah dianggap tidak bertentangan dengan ketentuan Pasal 4, Pasal 5 dan Pasal 6 UUM. 


\section{Mengenai Persamaan Pada Pokoknya}

Tergugat II menyatakan bahwa sesuai dengan ketentuan Pasal 6 ayat (1) huruf a UUM, Direktorat Jenderal akan menolak permintaan pendaftaran merek yang mempunyai persamaan pada pokoknya atau keseluruhannya dengan merek pihak lain yang sudah terdaftar lebih dahulu untuk barang atau jasa yang sejenis. Untuk selanjutnya berdasarkan ketentuan Pasal 6 ayat (1) huruf a UUM, merek yang ditolak pendaftarannya harus memenuhi 2 unsur yakni: Untuk menentukan kedua merek sengketa tersebut mempunyai persamaan pada pokoknya atau tidak mempunyai persamaan pada pokoknya; dan Untuk menentukan apakah jenis barang kedua merek sengketa tersebut sejenis atau tidak sejenis.

Tergugat II menyatakan bahwa jika dicermati kedua merek sengketa tersebut terdapat perbedaan jenis barang (barang yang tidak sejenis) dan kelas barang di antara merek Calcimax daftar No. IDM000090867 atas nama Tergugat I dengan merek Calcimex daftar nomor IDM000016054, merek Calcimex Vitalize daftar No. IDM000183280, Merek Calcimex Vitagold daftar nomor IDM000183281 untuk melindungi jenis barang susu dan hasil-hasil produksi susu (kelas 29), dan Calcimex Vitalize daftar No. IDM000166617 untuk melindungi jenis barang kakao, produk-produk kakao (atau mengandung kakao sebagai unsur utama), khususnya minuman dengan bahan dasar coklat, minuman coklat dengan susu, susu coklat (kelas 30) atas nama Penggugat terlihat jelas perbedaan kelas barang maupun jenis barang.

Adapun maksud dan tujuan daripada ketentuan pada Pasal 6 ayat (1) huruf a UUM adalah mempunyai persamaan pada pokoknya atau keseluruhannya dengan merek milik orang lain yang telah terdaftar untuk barang dan/atau jasa yang sejenis. Dengan demikian terdaftarnya merek Calcimax milik Tergugat I dalam Daftar Umum Merek dikarenakan tidak mempunyai persamaan pada pokoknya atau keseluruhan dengan merek Calcimex milik Penggugat dalam hal dipergunakan terhadap barang yang tidak sejenis dan tidak termasuk dalam kelas barang yang sama.

Tergugat II menyatakan bahwa dalam menilai suatu merek yang digunakan di pasaran masyarakat pada saat ini telah memiliki kemampuan (kepintaran) dan berpendidikan dalam arti kata masyarakat dapat menilai atau membedakan pemakaian merek-merek di pasaran apalagi terlihat jelas perbedaan di antara kedua merek sengketa tersebut, merek Calcimex untuk jenis barang susu atas nama Penggugat banyak dijual bebas di masyarakat umum tidak memerlukan resep dokter dan dengan mudah masyarakat sebagai konsumen dapat mengenalnya sedangkan merek Calcimax untuk vitamin biasanya diperdagangkan di apotek atau pun tempat-tempat tertentu. Dalam hal peredaran dan konsumsi obat vitamin tersebut harus melalui resep dokter ataupun apoteker dan jarang dijual bebas pada masyarakat umum. Dengan demikian masyarakat tidak akan terkecoh apabila menemukan pemakaian kedua merek sengketa tersebut di pasaran.

Tergugat II menyatakan bahwa apabila merekmerek sengketa tersebut telah terdaftar dalam Daftar Umum Merek, merek Tergugat I tidak relevan lagi ditinjau ada tidaknya persamaan pada pokoknya atau keseluruhannya untuk dijadikan sebagai alasan hukum, karena secara hukum merek Calcimax milik Tergugat I telah melalui proses pemeriksaan subtantif berdasarkan pada Pasal 6 ayat (1) huruf a UUM, Tergugat II berpendapat bahwa di antara kedua merek tersebut tidak terpenuhi unsur-unsur persamaan pada pokoknya atau keseluruhannya, maka sesuai dengan ketentuan pada Pasal tersebut di atas Direktorat Jenderal Hak Kekayaan Intelektual sudah selayaknya menyetujui permintaan pendaftaran merek atas nama Tergugat I.

\section{Pertimbangan Hukum yang Menjadi Dasar Putusan Pengadilan Niaga Jakarta No. 28/Merek/ PN.Niaga.Jakarta Pusat}

Dalam perkara ini, setelah menilai dalil gugatan dari Penggugat serta sangkalan dari pihak para Tergugat, Majelis Hakim menyimpulkan pokokpokok yang dipersengketakan dalam masalah ini adalah: Pertama, Apakah merek milik Penggugat mempunyai persamaan pada pokoknya dengan merek milik milik Tergugat I? Kedua, Apakah pendaftaran merek Calcimax oleh Tergugat I didasarkan atas asas itikad tidak baik sehingga harus dibatalkan? Ketiga, Apakah merek Calcimex milik Penggugat dapat dikatakan sebagai merek terkenal?

Dalam hal ini Majelis Hakim menilai bahwa pengertian merek berdasarkan UUM Pasal 1 butir 1 mendefinisikan pengertian merek adalah Tanda yang berupa gambar, nama, kata, huruf-huruf, angkaangka, susunan warna, atau kombinasi dari unsur- 
unsur tersebut yang memiliki daya pembeda atau digunakan dalam kegiatan perdagangan barang dan jasa.

Majelis Hakim berpendapat bahwa merek dapat berupa tanda apa saja, unsur-unsur tersebut di atas dapat berdiri sendiri atau kombinasi di antaranya, yang terpenting disini fungsi merek adalah sebagai unsur yang menandai atau memiliki daya pembeda atas suatu produk barang atau jasa dengan produk lain, di samping itu juga berfungsi sebagai jaminan kualitas mutu yang memberikan daya tarik tersendiri terhadap konsumen.

Mengenai persamaan pada pokoknya dan keseluruhannya Majelis Hakim dapat memberikan penilaian yang mendasarkan pada penjelasan Pasal 6 ayat (1) UUM menegaskan bahwa kemiripan yang disebabkan oleh adanya unsur-unsur yang menonjol antara merek yang satu dengan merek yang lain, yang dapat menimbulkan kesan adanya persamaan baik yang mengenai bentuk, cara penempatan, cara penulisan atau kombinasi antara unsur-unsur atau pun persamaan bunyi ucapan yang terdapat dalam merek-merek tersebut.

Dari definisi tersebut, apabila dihubungkan dengan pengertian merek, Majelis Hakim menafsirkan bahwa yang dimaksud dengan "unsurunsur yang menonjol" disini maksudnya adalah keseluruhan dari unsur-unsur yang tertera dalam merek itu sendiri, seperti unsur gambar, unsur nama, unsur kata, unsur huruf, unsur angka-angka, unsur susunan warna atau kombinasi diantaranya sebagai satu kesatuan. Menurut Yurisprudensi Mahkamah Agung dalam Putusan Nomor: 279. PK/Pdt/1992 tanggal 6 Januari 1998 menyatakan merek yang digunakan sama secara keseluruhannya atau mempunyai persamaan pada pokoknya dapat dideskripsikan: Sama bentuk (similarity of form); Sama komposisi (similarity of composition), Sama kombinasi (similarity of combination); Sama unsur elemen (similarity of elements); Persamaan bunyi (sound similarity); Persamaan ucapan (phonetic similarity); dan Persamaan penampilan (similarity in appereance).

Majelis hakim disini berpendapat bahwa cara untuk menentukan suatu merek mempunyai persamaan pada pokoknya dengan merek lain atau tidak adalah dengan membandingkan kedua merek tersebut, dengan cara melihat secara visual persamaan dan perbedaan-perbedaannya, memperhatikan ciri- ciri penting dan kesan kemiripan atau perbedaan yang timbul, sehingga apabila merek-merek tersebut dipastikan sama atau hampir sama, maka pelanggaran merek telah terjadi.

Sebagai tambahan Majelis Hakim mencermati pula ketentuan Pasal 6 ayat (1) UUM mengatur bahwa permohonan pendaftaran merek harus ditolak oleh Direktorat Jenderal Merek apabila mempunyai persamaan pada pokoknya atau keseluruhannya dengan merek pihak lain yang sudah terdaftar terlebih dahulu untuk barang dan/atau jasa sejenis. Jika hal itu terjadi menurut Pasal 76 ayat (1) UUM mengatur bahwa pemilik merek terdaftar dapat mengajukan gugatan terhadap pihak lain yang menggunakan merek yang mempunyai persamaan pada pokoknya atau keseluruhannya untuk barang dan jasa sejenis berupa: Gugatan ganti rugi; dan/atau Penghentian semua perbuatan yang berkaitan dengan penggunaan merek tersebut.

Dengan memperhatikan 2 (dua) pasal tersebut, Majelis Hakim berpendapat bahwa kalimat: yang mempunyai persamaan pada pokoknya dan keseluruhannya untuk barang dan jasa sejenis harus dibaca secara utuh yang memberikan arti bahwa merek mempunyai persamaan pada pokoknya tersebut haruslah untuk barang dan jasa sejenis untuk menghindari adanya pengecohan terhadap konsumen atas produk barang yang dilindungi oleh merek dalam suatu jenis barang pada kelas yang sama tersebut.

Setelah Majelis Hakim membandingkan antara merek Calcimex dengan pendaftaran No. 342289 tertanggal 28 Agustus 1995 di kelas 29 (bukti P-9) yang telah diperpanjang No. Daftar No. M000016054 tanggal 14 September 2004 (bukti P-10) dan P-11 tentang petikan resmi pendaftaran merek Calcimax dan gambar daftar IDM000166617 tanggal 30 Juni 2008 untuk kelas 30, dibandingkan dengan merek Calcimax Daftar Nomor: IDM000166617 taggal 26 Juli 2004 (bukti P-12/TI-1), maka Majelis Hakim berpendapat bahwa merek Calcimex merek penggugat adalah untuk melindungi jenis barang kelas 29 (P-9 dan P-10) untuk melindungi produk susu dan kelas 30 (bukti P-11) untuk melindungi produk kakao, sedangkan merek Calcimax milik Tergugat I untuk melindungi barang kelas 5 (bukti TI-1, bukti TI-2a dan TI-2b serta P-12) yaitu vitamin.

Dari hal tersebut, Majelis Hakim tidak dapat melihat bahwa merek Calcimex milik Penggugat juga untuk melindungi jenis barang kelas 05 yang sama 
dengan merek milik Tergugat, sedangkan secara yuridis merek yang telah didaftarkan di Direktorat Jenderal HKI cq Direktorat Merek, Departemen Hukum dan HAM RI oleh Penggugat untuk kelas barang 29 dan 30, sehingga jika Penggugat mempunyai hak atas merek Calcimex yang digunakan untuk melindungi barang kelas 05 seharusnya untuk memenuhi persyaratan sebagaimana ditentukan dalam Pasal 68 ayat (1) dan ayat (2) UUM sebagai pihak yang berkepentingan. Penggugat harus mengajukan permohonan pendaftaran merek Calcimex untuk melindungi barang- barang ada kelas 05 pada kantor Direktorat HKI Departemen Hukum dan HAM RI tersebut terlebih dahulu.

Majelis Hakim berpendapat bahwa meskipun dalam ketentuan sebagaimana dimaksud pada ayat (1) huruf b dimana permohonan harus ditolak oleh Direktorat Jenderal merek tersebut jika mempunyai persamaan pada pokoknya atau keseluruhannya dengan merek terkenal milik pihak lain untuk barang dan/atau jasa sejenis atau dapat pula diberlakukan terhadap barang dan jasa tidak sejenis sepanjang memenuhi persyaratan tertentu yang akan ditetapkan oleh Peraturan Pemerintah, namun hingga perkara ini diputus Peraturan Pemerintah sebagaimana yang diamanatkan oleh Pasal 6 ayat (2) UUM tersebut belum ditetapkan atau belum ada.

Majelis Hakim berpendapat bahwa dalil Penggugat yang secara substantif mengajukan gugatan pembatalan merek milik Tergugat 1 adalah tidak beralasan hukum sehingga harus ditolak, sehingga Majelis Hakim berpendapat bahwa Penggugat telah gagal membuktikan dalil-dalil gugatannya dan gugatan Penggugat harus ditolak seluruhnya.

Pasal 4 ayat (1) dalam UUM, Merek tidak didaftar atas dasar permohonan yang diajukan oleh pemohon yang beritikad tidak baik. Dalam Penjelasan pasal ini menerangkan bahwa pemohon yang beritikad baik adalah pemohon yang mendaftarkan mereknya secara layak dan jujur tanpa ada niat apa pun untuk membonceng, meniru, atau menjiplak ketenaran merek pihak lain demi kepentingan usahanya yang berakibat kerugian pada pihak lain itu atau menimbulkan kondisi persaingan curang, mengecoh, atau menyesatkan konsumen.

Faktor yang harus diperhatikan berkenaan dengan asas itikad baik dalam pendaftaran suatu merek, maka sesuai dengan penjelasan Pasal 4 UUM, bahwa harus memenuhi unsur-unsur berikut: Pertama, Merek yang akan didaftar diperoleh secara layak dan jujur; Kedua, Merek yang akan didaftar tidak ada kesengajaan untuk membonceng,meniru, menjiplak merek lain; Ketiga, Merek yang akan didaftarkan tidak ada kesengajaan untuk menimbulkan persaingan curang.

Dari pihakTergugat I tidak ada sama sekali ingin mendompleng ketenaran milik Penggugat. Nama Calcimax diambil karena ada persamaan dengan brand milik perusahaannya yaitu Nutrimax. Hal itu ditujukan untuk mempermudah karena memang nanti produknya memang suplemen berupa kalsium. Dari situ muncullah nama "Calci" kemudian ditambahkan nama belakang produknya yaitu "Max" yang mana jika ditambahkan menjadi Calcimax. Tidak ada niat sama sekali dari perusahaannya untuk mendompleng ketenaran milik Penggugat. Tergugat I juga telah mengecek dari kelas-kelas yang sejenis suplemen, tidak ada yang menggunakan nama itu. Tergugat I mengaku kaget ketika ada gugatan dari Penggugat. Dari situ penulis dapat menilai bahwa pihak Tergugat I mendaftarkan mereknya secara layak dan jujur, tidak ada kesengajaan untuk membonceng, meniru, menjiplak merek lain, dan tidak ada kesengajaan untuk menimbulkan persaingan curang.

Dalam Pasal 6 ayat (1) huruf a UUM menyatakan bahwa permohonan harus ditolak oleh Direktorat Jenderal apabila mempunyai persamaan pada pokoknya atau keseluruhannya dengan Merek milik pihak lain yang sudah terdaftar lebih dahulu untuk barang dan/atau jasa yang sejenis. Dalam hal ini terdapat perbedaan jenis barang dan kelas barang antara merek Calcimex milik Penggugat dan merek Calcimax milik Tergugat I dimana merek Calcimex milik Penggugat didaftarkan untuk melindungi jenis barang susu dan hasil-hasil produk susu (kelas 29) dan kakao (mengandung kakao sebagai unsur utama), khususnya minuman berbahan dasar coklat, minuman coklat dengan susu, susu coklat (kelas 30) sedangkan merek Tergugat I hanya didaftarkan pada kelas 05, yaitu vitamin. Jadi, adapun ketentuan dari Pasal 6 ayat (1) huruf a UUM tersebut tidak dapat berlaku karena produk milik Penggugat dan Tergugat I tidak berada dalam kelas yang sama.

Dalam kasus ini, pendapat Majelis Hakim bahwa kalimat: yang mempunyai persamaan pada pokoknya dan keseluruhannya untuk barang dan jasa sejenis harus dibaca secara utuh yang memberikan arti 
bahwa merek mempunyai persamaan pada pokoknya tersebut haruslah untuk barang dan jasa sejenis untuk menghindari adanya pengecohan terhadap konsumen atas produk barang yang dilindungi oleh merek dalam suatu jenis barang pada kelas yang sama tersebut adalah sangat tepat karena merek Calcimex milik Penggugat secara yuridis merek yang telah didaftarkan di Direktorat Jenderal HKI cq Direktorat Merek, Departemen Hukum dan HAM RI oleh Penggugat untuk kelas barang 29 dan 30. Jika Penggugat mempunyai hak atas merek Calcimex yang digunakan untuk melindungi barang kelas 05 seharusnya untuk memenuhi persyaratan sebagaimana ditentukan dalam Pasal 68 ayat (1) dan ayat (2) UUM sebagai pihak yang berkepentingan, Penggugat harus mengajukan permohonan pendaftaran merek Calcimex untuk melindungi barang-barang ada kelas 05 pada kantor Direktorat HKI cq Departemen Hukum dan HAM RI tersebut terlebih dahulu.

\section{PENUTUP}

\section{Kesimpulan}

Berdasarkan uraian dan pembahasan, maka disimpulkan bahwa dalam pertimbangan hakim mengenai itikad baik, persamaan pada pokoknya, dan merek terkenal tersebut dapat disimpulkan dari pihak Tergugat I yaitu Calcimax, tidak ada sama sekali ingin mendompleng ketenaran milik Penggugat. Adanya nama Calcimax tersebut karena ada kemiripan dengan brand milik perusahaannya yaitu Nutrimax, yangmemproduksi suplemen yaitu berupa kalsium. Dari situ muncullah nama Calci kemudian ditambahkan nama belakang produknya yaitu Max yang mana jika ditambahkan menjadi Calcimax. Tidak ada niat sama sekali dari perusahaannya untuk mendompleng ketenaran milik Penggugat. Dari situ saya dapat menilai bahwa pihak Tergugat I mendaftarkan mereknya secara layak dan jujur, tidak ada kesengajaan untuk membonceng, meniru, menjiplak merek lain, dan tidak ada kesengajaan untuk menimbulkan persaingan curang.

Berdasarkan gugatan untuk kasus persamaan pada pokoknya dengan merek dagang milik penggugat, dalam hal ini terdapat perbedaan jenis barang dan kelas barang antara merek Calcimex milik Penggugat dan merek Calcimax milik Tergugat I dimana merek Calcimex milik Penggugat didaftarkan untuk melindungi jenis barang susu dan hasil-hasil produk susu (kelas 29) dan kakao (mengandung kakao sebagai unsur utama), khususnya minuman berbahan dasar coklat, minuman coklat dengan susu, susu coklat (kelas 30) sedangkan merek Tergugat I hanya didaftarkan pada kelas 05 , yaitu vitamin. Dalam ketentuan dari Pasal 6 ayat (1) huruf a UUM tersebut tidak dapat berlaku karena produk milik Penggugat dan Tergugat I tidak berada dalam kelas yang sama. Oleh karena itu, dalam kasus ini tidak ada persamaan pada pokoknya terhadap merek dagang Penggugat.

\section{Rekomendasi}

Pemegang merek dagang terhadap produk terkenal mempunyai perlindungan hukum yang sama dengan pemegang merek tidak terkenal, walaupun pemegang merek berstatus warga negara asing, asalkan mempunyai itikad baik dan sejalan dengan penegakan hukum merek di Indonesia sebagaimana tertuang dalam Pasal 6 UUM.

\section{DAFTAR PUSTAKA}

\section{Peraturan Perundang-undangan:}

Undang-Undang Republik Indonesia Nomor 15 Tahun 2001 tentang Merek. Lembaran Negara Nomor 110 Tahun 2001.

Paris Convention for the Protection of Industrial Property TRIPs Agreement.

HIR.

Peraturan Pemerintah Nomor 24 Tahun 1993 tentang Daftar Kelas Barang dan Jasa.

\section{Buku:}

Manan, Bagir. 2005. Hak Kekayaan Intelektual dan Perkembangannya. Jakarta: Pusat Pengkajian Hukum.

Direktorat Jendral Hak Kekayaan Intelektual. 2003. Buku Panduan Hak Kekayaan Intelektual 2003. Tangerang: Direktorat Jenderal Hak Kekayaan Intelektual-Asian Pacific Economic Cooperation.

Hasibuan, H.D. Effendy. 2003. Perlindungan Merek: Studi Mengenai Putusan Pengadilan Indonesia dan Amerika Serikat. Jakarta: Program Pasca Sarjana Fakultas Hukum Universitas Indonesia. Sutjipto, H.M.N. Purwo. 2000. Pengertian PokokPokok Hukum Dagang Indonesia. Jakarta: Djambatan.

Firmansyah, Hery. 2011. Perlindungan Hukum terhadap Merek Panduan Memahami Dasar 
Hukum Penggunaan dan Perlindungan Merek. Yogyakarta: Pustaka Yustitia.

Maulana, Insan Budi. 2005. Bianglala HaKI: Hak Kekayaan Intelektual. Jakarta: Hecca Mitra Utama.

Zed, Mestika. 2004. Metode Penelitian Kepustakaan. Jakarta: Yayasan Obor Indonesia.

Djumhana, Muhammad. 2006. Perkembangan Doktrin dan Teori Perlindungan Hak Kekayaan Intelektual. Cet. I. Bandung: Citra Aditya Bakti.

Saidin, OK. 2004. Aspek Hukum Hak Kekayaan Intelektual. Cet. IV. Jakarta: Rajagrafindo Persada.

Usman, Rachmadi. 2003. Hukum Hak atas Kekayaan Intelektual. Bandung: Alumni.

Margono, Suyud. 2002. Pembaharuan Perlindungan Hukum Merek. Bandung: Novindo Pustaka Mandiri.
Lindsey, Tim. 2004. Hak Kekayaan Suatu Pengantar. Bandung: Alumni.

Subroto. Mengukur Kinerja Merek. Swasembada. No. 04/XVII. 22 Pebruari 7 Maret 2001.

Utomo, Tomi Suryo dkk. 2006. Hak Kekayaan Intelektual: Suatu Pengantar. Bandung: Alumni.

\section{Jurnal:}

Daritan, Protasius. 1997. Hukum Merek dan Persengketaan Merek di Indonesia. Skripsi Fakultas Hukum Universitas Indonesia. tidak dipublikasikan. Jakarta.

Purwadi, Ari. 1992. Aspek Hukum Perdata pada Perlindungan Konsumen. Yuridika. Majalah Fakultas Hukum Universitas Airlangga, Nomor 1 dan 2. Tahun VII. Jan-Feb-Mar. Surabaya. 